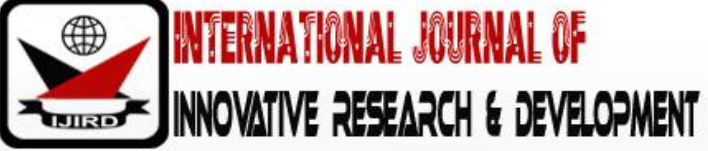

ISSN 2278 - 0211 (Online)

\section{Attitude of Pre-Service Teachers towards Inclusive Education}

\author{
Jesse James G. Gellor Jr. \\ Student, Department of College of Science and Technology Education, \\ University of Science and Technology of Southern Philippines, Philippines
}

\begin{abstract}
:
This study was conducted to find out the influence of past experience and newly acquired knowledge to the attitude of preservice teachers toward inclusive education. Data were gathered through a survey of 270 fourth year students of the College of Education of Bukidnon State University who had their practicum during the first semester of school year 2018-2019 and 15 FGD participants.

The findings revealed that only few of the pre-service teachers included in the study had exposure to inclusive education and this is in terms of trainings/ seminars and/ or working with learners with special needs. This past experiences were found to significantly correlate with the participants' newly acquired knowledge. However, there is no significant relationship between past experiences and attitude toward inclusive education and newly acquired knowledge and attitude toward inclusive education. Thus, attitude toward inclusive education is more than the function of past experiences and newly acquired knowledge. It is adequate preparation that gives teachers confidence with their competence to handle learners with special needs.
\end{abstract}

From the results of the study, a teaching guide was developed to ensure the implementation of inclusive education not only for the pre-service education but also when pre-service teachers eventually become professional teachers.

Keywords: Attitude, pre-service teachers, inclusive education

\section{Introduction}

Historically, Children with special needs are often hidden from the public eye (Alur, 2002; Griffin \& Shevlin, 2011) recently; Children with disabilities were educated in separate classes or in separate schools. The public got used to the idea that special education meant self-contained education. However, today a new educational conversation in special education show a movement from special education to inclusive education which guarantees the right of these children to receive appropriate education within the regular or inclusive classroom setting. Inclusive education embraces the philosophy of accepting all children regardless of ability or disability, race, with support from school staff, students, parents, and the community. Consequently, special and general education teachers are facing the challenge to providing services in general education classroom that historically provided in two different educational setting.

Another cause of inclusive education on why it is gaining its popularity is the talk on teachers' preparedness to handle inclusive education classroom. The Philippine department of education is committed to address the concerns on inclusive education as a core strategy for Education for All (EFA) as an approach to reform the educational system by accommodating all children regardless of physical intellectual social, emotional, linguistic or other conditions in the general classroom (Ains cow and Miles, 2008). Inclusive education is a direct result of the DepEd Order No. 72 s. 2009 that the Department of Education has organized the urgency to address this issue. The journey toward inclusion has been greatly influenced by major legislative enactment such as the United Nation Convention on the Right of the Child (UNCRC, 1989) The major thrust for the inclusive education approach in the Philippines is the Salamanca statement and framework for action on inclusive education (UNESCO, 1994). According to the UNESCO (2009b) policy guidelines acknowledges the important role of the teacher in supporting the process leading to an inclusive education program. In response to the 21st century Philippine teacher's education framework states that teacher attitude and legislative policy go hand in hand (Shade \& Stewart, 2001).

Today only little scholarly research focused on the attitude of teachers regarding educating students with disability in the region. These suggest that It is therefore important to determine what attitude of preservice teachers have toward special education before they will be taken in the teaching work force. Quite a number of foreign studies in special education on the attitude of general education teachers toward educating pupils with special educational needs (SEN) in the regular classroom have been put forward as a decisive factor in making schools more inclusive. On the other hand, the pre-service teachers might hold contrasting views regarding inclusivity. For instance, it has been reported that teachers with more negative attitude were found to have low expectations for individuals with disabilities (Wilczenski,1993 as cited by Loreman, 2007). Moreover, Teachers with positive views of inclusion have more confidence in their abilities and 
committed to accommodate students' needs in inclusive setting. (Campbell, Gilmore, \& Cuskelly, 2003; Norwich, 1994). It is with the above premise that this study is conceptualized.

\section{Framework of the Study}

One of the visions of UNESCO (2004) is to promote inclusive education among those that have been discriminated on the basis of their physical, mental and behavioral disabilities. This idea of inclusive education is now gaining ground in the Philippines. In fact, the Department of Education has made tremendous effort to abide by the principles of inclusivity in education as it tries to make children become educated regardless of their physical, learning disabilities and any form of disadvantage.

Inclusive education means that all students attend and are welcomed by schools in age appropriate, regular classes are supported to learn, contribute and participate in all aspect of school life. Furthermore inclusive education is a term used to describe one opinion for the placement of special education student in public schools. Successful inclusion of children with disabilities in our school system relies on the idea that all children should have equal access to a quality education.

Another theory that serves as a framework of this study is attitude of the person toward anything for implementation. The word attitude originated from the (Latin word apyus) is defined within the framework of social psychology as a mental preparation for action. It will also determine what each individual will see or hear, think and do. They are rooted in experience and not become automatic routine. It refers to affective, cognitive, and behavioral components that correspond respectively to ones evaluation of, knowledge of, and predisposition to act toward the object of the attitude (Ostrom, 1969).

According to the FSU Center for Prevention and Early Intervention Policy (2002), adequate and appropriate resources, support for students and teachers, and teacher training and planning time, are essential in assuring the success of inclusive programming and the commitment to a goal of success for all students. As a result of the wide promotion of inclusion in recent years, many students with special needs are now being served in general education classrooms (Mastropieri \& Scruggs, 2001). Just as inclusion promotes potential advantages by ensuring access to general education

\subsection{Conceptual Framework}

This study will share the assumptions from studies conducted on inclusive education that teachers' attitudes may act to facilitate or constrain the implementation of inclusion. Assumptions suggest that attitude toward a behavior may be influenced by past experiences previous knowledge and newly acquired knowledge (Beck and Azjen, 1991; Azjen and Fishbein, 1977). Attitude plays a significant role in determining behavior (Azjen \& Fishbein, 1977); therefore it is significant to know the factors shaping the pre service teachers attitude as we seek to include children with disability in the general classroom. More specifically, this study is anchored on the premise that the attitude of mainstream teacher toward the inclusion of students with disabilities are influenced by past experience (previous experience with teaching student with disability), and newly acquired knowledge (professional development or training modules).

Figure 1 illustrates the schema of the study and it shows that the participants' past experiences and newly acquired knowledge influence the attitude of pre-service teachers toward inclusive education. Hence, past experiences and newly acquired knowledge are treated as independent variables in the study while attitude toward inclusive education is considered the dependent variable. From the results, a teaching guide was developed and proposed to ensure the implementation of inclusive education at Bukidnon State University.

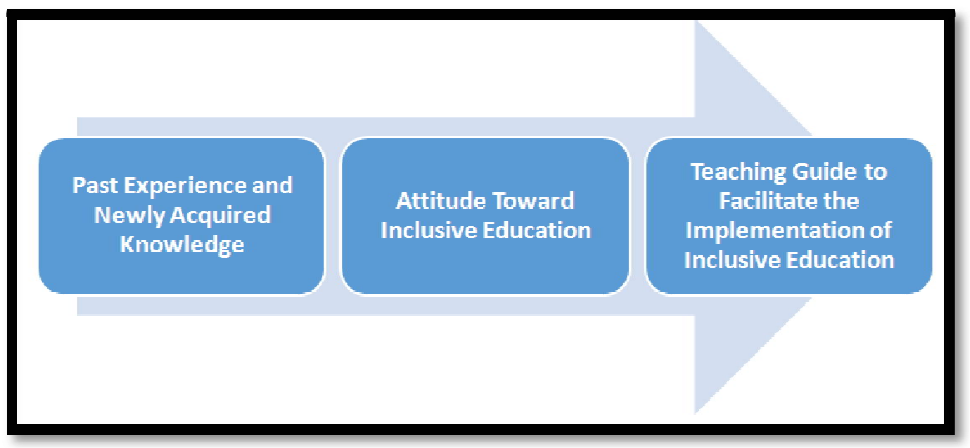

Figure 1: Schema of the Study Showing the Interplay of Variables

\subsection{Purpose of the Study}

The purpose of the study is to determine the influence of past experiences, prior knowledge, and newly acquired knowledge to the attitude of pre-service teachers toward inclusive education. This is based on the assumption that teachers' attitude toward inclusive education can have a significant impact on the success of this new approach.

\subsection{Research Questions}

The study will endeavor to find answers to the following questions: education?

- What are the pre-service teachers' past experiences and newly acquired knowledge relative to inclusive

- What is the attitude of pre-service teachers toward inclusive education? 
- Is there a significant relationship between the teachers' past experiences, newly acquired knowledge, and attitude toward inclusive education?

- From the findings, what teaching guide can be developed to ensure the implementation of inclusive education specifically at Bukidnon State University?

\section{Methodology}

\subsection{Research Design}

This study employed the relational research design as it intends to find out the extent of relationship between the teachers' past experiences, newly acquired knowledge and their attitude toward inclusive education. According to Fox (1969 in Andales, 2001), the distinguishing characteristics of this type of study is its system, which allows estimation of relationship between study variables. With the use of statistical measures of correlation, the researcher will be able to find out whether the relationship between variables is positive or negative.

\subsection{Research Locale}

The study was conducted at Bukidnon State University since the chosen participants were students of the university. The College of Education was purposely selected because it is the flagship program of the university with the primary aim of producing well-trained teachers to work with preschool, elementary and secondary levels by offering various areas of study.

Bukidnon State University is located in the capital town of Malaybalay City, Bukidnon and is strategically positioned to serve region X, Region XI, and CARAGA Region and other out laying cities and province of Mindanao. It is one of the leading educational institutions originally founded as a teacher-training school.

\subsection{Participants of the Study}

There were two kinds of participants in this study. One is the 270 survey participants comprising the total population of pre-service teachers who had their practicum during the first semester of school year 2018-2019. This population is chosen with the assumption that they already have developed knowledge and attitude about inclusive education.

Moreover, the other participants were those 15 pre-service teachers who participated in the FGD. One group had eight participants while the other had seven with a total of 15 FGD participants.

\subsection{Instrumentation}

There were two research instruments used in this study. One is the survey instrument while the other is the FGD guide questions. The survey instrument is based on the study of Pham (2008). Pham adapted the instrument, with some modifications, from the Attitude towards Mainstreaming Scale (TMS) developed by Larrivee and Cook (1979). This standardized questionnaire was chosen because it was designed specifically for inclusive education.

To gather data on past experiences, the participants were asked about the: (1) trainings/ seminars/ workshops on inclusive education they attended; (2) experience they had teaching or working with learners with special needs/ disabilities; and (3) for those who had experienced, they were further asked about the kind of impairment they were exposed to. Meanwhile, the newly acquired knowledge of inclusive education was measured using a 10-item Likert Scale.

As to the participants' attitude toward inclusive education, the instrument was modified from Larrivee and Cook's ATMS (1979 cited in Pham, 2008). The original ATMS (1979) contained 30 Likert-scale items. Pham removed Item 26 of the original scale since it was the only item concerning students with special needs' parents. Hence, this study made use of the 29 items instead of the 30 standardized items. Lastly, the use of the terms "students with disabilities" was changed to "students with special needs."

Moreover, with regard to the FGD guide questions, items were classified according to the variables measured. For past experiences, the participants were asked the following questions: Have you had experience or exposure with people with special needs? Describe briefly your experience. Do you know someone personally or have you taught a child with special needs? Do you think your experience help you prepare to teach children with special needs? Why? Did you receive training in teaching students with special needs? Is it necessary for students in the college of education to acquire training in teaching students with special needs regardless of their chosen field of specialization? Why or why not?

For newly acquired knowledge, the participants were asked the following questions: Do you think that pre-service education teachers have sufficient exposure/ training for inclusion? Do you support the idea of including student with disabilities in the general education classroom? Why? What kind of knowledge or training do you think is useful in preparing pre-service teachers like yourself to be better prepared to teach students with special needs in the mainstream classroom?

Furthermore, the following questions were asked for the attitude component: As a general education future teacher, are you willing to teach students with special needs in your classroom?Do you think that students, with and without special needs, benefit from inclusion? Why or why not? Do you feel prepared to teach students with special needs in your classroom? Why or why not? As a student teacher, what concerns you most when handling students with special needs in the general education classroom? 


\subsection{Reliability and Validity}

According to Frazer, et.al. (2000, as cited by Pham, 2008), a questionnaire is valid "if it measures what it is supposed to measure and it is reliable if the responses are consistent and stable." De Vaus and de Vaus (2001) also added that the best way to create reliability is to use well-tested questions from reputable questionnaires. The use of ATMS by Larrivee and Cook (1979) and Pham (2008) lent support for reliability and validity of this study.

Moreover, to further strengthen the reliability and validity of the instrument, it was pilot tested to 50 fourth year education students of Bukidnon State University who took their practicum during the second semester and, thus, not included in the study.

\subsection{Data Gathering Procedure}

In gathering the data, the researcher first sought the approval of the university for the conduct of the study. The implementation strictly adhered to the ethical standards of the University. As such, only those who gave their consent to participate in the study were included. They were also fully informed of the intention of the study and how the results will be used. The participants were assured of strict confidentiality of the information divulged in the study.

To facilitate the focus group discussion, the pre-service teachers were asked whether they are willing to answer some questions about their views on inclusive education. Because they gladly accepted, they were set for an interview date. Three days later, two FGDs were scheduled. The interviews were conducted in English but participants were allowed to choose the language with which they felt most comfortable. The teachers were interviewed in order to further investigate their knowledge, thoughts and feelings regarding children with special needs, how they perceived inclusive education and their suggestions on how to address the challenges. The insights gained from these interviews provided the researcher with more sense into how each pre-service teacher viewed children with special needs and their idea about inclusive education. Their answers were recorded through video camera and audio recorded while they were speaking. The researcher relied on the video and audio recording to capture all the responses. Each FGD lasted at the maximum of one hour for each group. After the Focus Group Discussion (FGD), the information obtained were transcribed, data analyzed and interpreted based on the research question.

\subsection{Statistical Treatment}

Data gathered for Problems 1 and 2 were treated using descriptive statistics such as frequency and percent distributions, and weighted means. To determine the weighted mean, the following rating scale was followed:

3.26 - 4.00 Strongly Agree

$2.51-3.25$ Agree

$1.76-2.50$ Disagree

1.00 - 1.75 Strongly Disagree

Moreover, data gathered for Problem 3 were treated with inferential statistics specifically the Pearson Product Moment Correlation. To facilitate the interpretation of the correlation coefficients, the following scale was used: \pm 0.00 to 0.30 (Negligible correlation);

\pm 0.31 to 0.50 (Low correlation);

\pm 0.51 to 0.70 (Moderate correlation);

\pm 0.71 to 0.90 (High correlation);

\pm 0.91 to 1.00 (Very high correlation);

\section{Results and Discussion}

4.1. Problem 1 What Are The Pre-Service Teachers' Past Experiences and Newly Acquired Knowledge Relative to Inclusive Education?

Table 1 presents the pre-service teachers' past experiences relative to inclusive education. Data show that only $16.3 \%$ of the participants attended trainings/seminars/workshops on inclusive education and $17.0 \%$ experienced teaching or working with learners with special needs. From the FGD (see Appendix D), one participant shared about the seminar she attended:

I have attended a seminar sir, here in our school auditorium on our guidance and counseling course subject. It was about inclusive education, but they only introduced the different types of disabilities. It wasn't enough sir because I think there should be a hands-on training. I believe special education should not only be based on theories, because we don't know whether a particular approach can actually be applicable to learners of the same disability but of different needs. It is really different sir if a teacher has a hands-on, actual encounter of the child with special needs. Moreover, in our course subject, I have also learned the dos and don'ts about teaching approaches that are just mere based on theories. They may be helpful, but they may not be really fit for a certain learner with a specific need. ---Tati

A closer look at Tati's experience revealed that the seminar she attended was embedded in the guidance and counselling course she took in that semester. It was a seminar on inclusive education but it only introduced the different types of disabilities. She is convinced that the seminar is not enough to gain confidence in handling special learners in the classroom. This means that hands-on training and not merely learning the theories will equip her to implement inclusive education when she gets to practice her profession.

Another FGD participant shared his past experience involving immersion in the field with learners with special needs as follows: 
At the beginning of the semester, the different disabilities of the children are really introduced and at the end of it, we were immersed in the field. Our instructor had us visit and made us have actual contact with these children so we could experience what it is really like to be with them based on what we have learned in class. ---Payos

\begin{tabular}{|c|c|c|}
\hline Indicators & Frequency & Percent \\
\hline $\begin{array}{c}\text { Attended Trainings/ Seminars/ Workshops on Inclusive } \\
\text { Education } \\
\text { Yes } \\
\text { No } \\
\text { Total }\end{array}$ & $\begin{array}{c}44 \\
226 \\
270\end{array}$ & $\begin{array}{c}16.3 \\
83.7 \\
100.0\end{array}$ \\
\hline $\begin{array}{c}\text { Experienced Teaching or Working with Learners with } \\
\text { Special Needs/ Disabilities } \\
\text { Yes } \\
\text { No } \\
\text { Total }\end{array}$ & $\begin{array}{l}\text { Frequency } \\
\\
46 \\
224 \\
270\end{array}$ & $\begin{array}{c}\text { Percent } \\
17.0 \\
83.0 \\
100.00\end{array}$ \\
\hline Kind of Impairment & Frequency & Percent \\
\hline Autism & 9 & 3.3 \\
\hline Deaf-Blindness & 1 & 0.4 \\
\hline Developmental Delay & 7 & 2.6 \\
\hline Emotional Disturbance & 1 & 0.4 \\
\hline Visual Impairment & 1 & 0.4 \\
\hline Hearing Impairment & 4 & 1.5 \\
\hline Intellectual Disability & 7 & 2.6 \\
\hline Orthopedic Impairment & 8 & 3.0 \\
\hline Speech and Language Disability & 4 & 1.5 \\
\hline Multi-disabilities & 2 & 0.7 \\
\hline Other Health Impairment & 1 & 0.4 \\
\hline Traumatic Brain Injury & 1 & 0.4 \\
\hline No Experience & 224 & 83.0 \\
\hline Total & 270 & 100.0 \\
\hline
\end{tabular}

Table 1: Pre-Service Teachers' Past Experiences Relative to Inclusive Education

Among the 15 FGD participants, 13 had experienced dealing with learners with special needs from among their family members, relatives, neighbors, or acquaintances. Only two participants had no exposure with learners with special needs.

Moreover, those participants who experienced working with learners with special needs were exposed to the following kinds of impairment: autism (9 or 3.3\%); deaf-blindness (1 or $0.4 \%$ ); developmental delay (7 or $2.6 \%$ ); emotional disturbance (1 or $0.4 \%$ ); visual impairment (1 or $0.4 \%$ ); hearing impairment (4 or 1.5\%); intellectual disability (7 or 2.6\%); orthopaedic impairment (8 or 3.0\%); speech and language disability (4 or 1.5\%); multi-disabilities (2 or $0.7 \%$ ); other health impairment ( 1 or $0.4 \%$ ); and traumatic brain injury ( 1 or $0.4 \%)$. This implies that pre-service teachers have very little exposure to inclusive education.

The Memorandum Order No. 77 series of 2017 of the Commission on Higher Education highlights the 21st century Philippine teachers' education framework. It emphasizes the pre-service preparation for teachers as a significant function of Teacher Education Institutions (TEIs). This implies the need for TEIs to provide pre-service teachers the appropriate and adequate exposures to inclusive education.

Table 2 presents the participants' newly acquired knowledge relative to inclusive education. Data show that the participants strongly agree that students have the right to the same education (WM=3.69). They also agree that: they had opportunities to observe inclusive education practices being implemented in the classroom (instruction, classroom management) during their teacher preparation program ( $\mathrm{WM=2.68);} \mathrm{they} \mathrm{were} \mathrm{provided} \mathrm{support} \mathrm{during} \mathrm{field} \mathrm{experience}$ (WM=2.99); their teacher preparation program offers opportunities for in-service training and professional development related to inclusion (WM=2.90); they participated in professional development related to working with students with special needs (WM=2.54); and that their field of specialization prepared them to handle and teach students with special needs (WM=2.77). 


\begin{tabular}{|c|c|c|c|}
\hline Indicators & $\mathbf{W M}$ & SD & Description \\
\hline $\begin{array}{l}\text { 1. I had opportunities to observe inclusive } \\
\text { education practices being implemented in the } \\
\text { classroom. ( instruction, classroom } \\
\text { management,) during my teacher preparation } \\
\text { program }\end{array}$ & 2.68 & 0.92 & Agree \\
\hline 2. Students have the right to the same education. & 3.69 & 0.75 & Strongly Agree \\
\hline $\begin{array}{l}\text { 3. My teacher education institution provided me } \\
\text { with opportunity to work with students with } \\
\text { disabilities }\end{array}$ & 2.49 & 1.02 & Disagree \\
\hline $\begin{array}{l}\text { 4. I was provided adequate support during field } \\
\text { experience in my teacher preparation } \\
\text { program. (feedback, guidance, resources.) }\end{array}$ & 2.99 & 0.96 & Agree \\
\hline $\begin{array}{l}\text { 5. My Teacher preparation program offers } \\
\text { opportunities for in-service training and } \\
\text { professional development related to inclusion. }\end{array}$ & 2.90 & 0.91 & Agree \\
\hline $\begin{array}{l}\text { 6. I participate in professional development related } \\
\text { to working with students with special needs. }\end{array}$ & 2.54 & 1.09 & Agree \\
\hline $\begin{array}{l}\text { 7. I have sufficient training to teach children with } \\
\text { special needs }\end{array}$ & 2.12 & 0.90 & Disagree \\
\hline $\begin{array}{l}\text { 8. I need more Training in order to appropriately } \\
\text { teach students with special needs. }\end{array}$ & 1.28 & 0.66 & Strongly Disagree \\
\hline $\begin{array}{c}\text { 9. My field of specialization prepared me to handle } \\
\text { and teach students with special needs. }\end{array}$ & 2.77 & 0.94 & Agree \\
\hline $\begin{array}{l}\text { 10. If I become a teacher in an inclusive classroom, } \\
\text { it will be difficult to adjust the curriculum for } \\
\text { students with special needs. }\end{array}$ & 2.02 & 0.87 & Disagree \\
\hline Grand Mean & 2.74 & 0.82 & Agree \\
\hline
\end{tabular}

Table 2: Pre-Service Teachers' Newly Acquired Knowledge on Inclusive Education WM=Weighted Mean $\mathrm{SD}=$ Standard Deviation

3.26-4.00 = Strongly Agree; 2.51-3.25 =Agree; 1.76-2.50 = Disagree; 1.00-1.75 = Strongly Disagree

Although a number of survey participants agree that their field of specialization prepared them to handle and teach students with special needs, the FGD participants, thinks otherwise. They revealed that their pre-service education teachers did not give them sufficient training/ exposure to handle inclusive education. In fact, one participant said:

It is not included in the curriculum. Before, people thought special education was just for people who want to teach children with special needs, but now it is very different. We are now in $21^{\text {st }}$ century learning, that's why the department of education is really pushing it through. Therefore, it should be included because it is just not paid much attention to.---Tati

However, they strongly disagree that they need more training in order to appropriately teach students with special needs (WM=1.28). They also disagree that: their teacher education institution provided them with opportunity to work with students with disabilities (WM=2.49); they have sufficient training to teach children with special needs (WM=2.12); and if they become teachers in an inclusive classroom, it will be difficult to adjust the curriculum for students with special needs ( $\mathrm{WM}=2.02)$. This supports the findings of previous studies that teachers often are not equipped to meet the needs of students with special needs (Allday, et.al., 2013; Casey, 2012...).

Moreover, the study of Muega (2016) on the perceptions of administrators, parents and teachers on inclusive education lend support to the findings of this study. In examining the current level of knowledge of the participants, Muega discovered that most of the participants are supportive of inclusive education, but are unsure if they have sufficient knowledge on the subject. Many participants believe there is a lack of training for teachers handling CSN (Muega and Echavia, 2011). Likewise, in the study of Angeles (2009) involving three public elementary schools in the Division of Bukidnon, Department of Education, a large percentage of teachers reiterated the need for inclusive education training. The said schools implemented a special education program in the division.

\subsection{Problem 2. What Is the Attitude of Pre-Service Teachers toward Inclusive Education?}

Table 3 presents the attitude of pre-service teachers toward inclusive education. Data show that the participants strongly agree that: the behavior of student with special needs generally requires more patience from the teacher than does the behavior of a "normal" student (WM=3.63); inclusion offers mixed group interaction which will foster understanding and acceptance of difference (WM=3.38); and the presence of students with special needs will promote acceptance of differences on the part of regular students (WM=3.32). From these indicators, the participants appeared to be favourable towards inclusive education. 
Moreover, they agree that: most of the methods teachers use with regular students in the classroom are appropriate for students with special needs (WM=2.52); the needs of students with disabilities can best be served through special separate classes (WM=3.06); the challenge of being in a regular classroom will promote the academic growth of the students with special needs (WM=3.04); the extra attention that students with special needs require will be to the detriment of the other students ( $\mathrm{WM}=2.73$ ); it is difficult to maintain order in a regular classroom that contains a student with special needs (WM=2.95); regular teachers possess a great deal of expertise necessary to work with students with special needs (WM=3.21); the behavior of student with special needs will set a bad example for other students (WM=3.11); isolation in a special class has a negative effect on the social and emotional development of the students with special needs (WM=2.84); inclusion of students with special needs will require significant changes in the regular classroom procedures (WM=3.09); the contact regular students have with students with special needs may be harmful $(\mathrm{WM}=2.74)$; regular teachers have sufficient training to teach students with special needs ( $\mathrm{WM}=2.80)$; inclusion will promote the students with special needs' social independence (WM=3.03); diagnostic/prescriptive teaching is better done by resource room or special teachers than regular classroom teachers (WM=2.93); the inclusion of students with special needs can be beneficial to regular students ( $\mathrm{WM}=2.73$ ); inclusion is likely to have a negative effect on emotional development of the students with special needs (WM=2.57); increased freedom in the classroom creates too much confusion (WM=2.52); and students with special needs should be given opportunity to function in the regular classroom setting where possible (WM=3.24).

\begin{tabular}{|c|c|c|c|}
\hline Indicators & WM & SD & Description \\
\hline $\begin{array}{l}\text { Most of the methods teachers use with regular students } \\
\text { in the classroom are appropriate for students with } \\
\text { special needs. }\end{array}$ & 2.52 & 0.91 & Agree \\
\hline $\begin{array}{l}\text { The needs of students with disabilities can best be } \\
\text { served through special, separate classes. }\end{array}$ & 3.06 & 0.91 & Agree \\
\hline $\begin{array}{l}\text { The behavior of a student with special needs generally } \\
\text { requires more patience from the teacher than does the } \\
\text { behavior of a "normal" student. }\end{array}$ & 3.63 & 0.68 & Strongly Agree \\
\hline $\begin{array}{l}\text { The challenge of being in the regular classroom will } \\
\text { promote the academic growth of the students with } \\
\text { special needs. }\end{array}$ & 3.04 & 0.82 & Agree \\
\hline $\begin{array}{l}\text { The extra attention that students with special needs } \\
\text { require will be to the detriment of the other students. }\end{array}$ & 2.73 & 0.87 & Agree \\
\hline $\begin{array}{l}\text { Inclusion offers mixed group interaction which will } \\
\text { foster understanding and acceptance of difference. }\end{array}$ & 3.38 & 0.71 & Strongly Agree \\
\hline $\begin{array}{l}\text { It is difficult to maintain order in a regular classroom } \\
\text { that contains a student with special needs. }\end{array}$ & 2.95 & 0.92 & Agree \\
\hline $\begin{array}{l}\text { Regular teachers possess a great deal of expertise } \\
\text { necessary to work with students with special needs. }\end{array}$ & 3.21 & 0.85 & Agree \\
\hline $\begin{array}{l}\text { The behavior of students with special needs will set a } \\
\text { bad example for other students. }\end{array}$ & 3.11 & 1.01 & Agree \\
\hline $\begin{array}{l}\text { Isolation in a special class has a negative effect on the } \\
\text { social and emotional development of the students with } \\
\text { special needs. }\end{array}$ & 2.84 & 0.94 & Agree \\
\hline $\begin{array}{c}\text { The students with special needs will probably develop } \\
\text { academic skills more rapidly in a special class than in a } \\
\text { regular classroom. }\end{array}$ & 2.22 & 0.82 & Disagree \\
\hline $\begin{array}{l}\text { Most students with special needs do not make } \\
\text { adequate attempt to complete their assignments. }\end{array}$ & 2.41 & 0.80 & Disagree \\
\hline $\begin{array}{c}\text { Inclusion of students with special needs will require } \\
\text { significant changes in the regular classroom } \\
\text { procedures. }\end{array}$ & 3.09 & 0.77 & Agree \\
\hline $\begin{array}{l}\text { Most students with special needs are well behaved in } \\
\text { the classroom. }\end{array}$ & 2.21 & 0.77 & Disagree \\
\hline $\begin{array}{l}\text { The contact regular students have with students with } \\
\text { special needs may be harmful. }\end{array}$ & 2.74 & 0.81 & Agree \\
\hline $\begin{array}{l}\text { Regular teachers have sufficient training to teach } \\
\text { students with special needs. }\end{array}$ & 2.80 & 0.92 & Agree \\
\hline $\begin{array}{c}\text { Students with special needs will monopolize the } \\
\text { teachers' time. }\end{array}$ & 2.46 & 0.83 & Disagree \\
\hline $\begin{array}{l}\text { Inclusion will promote the students with special needs' } \\
\text { social independence. }\end{array}$ & 3.03 & 0.74 & Agree \\
\hline $\begin{array}{l}\text { It is likely that a student with special needs will exhibit } \\
\text { behavior problems in regular classroom setting. }\end{array}$ & 2.28 & 0.75 & Disagree \\
\hline
\end{tabular}




\begin{tabular}{|c|c|c|c|}
\hline Indicators & WM & SD & Description \\
\hline $\begin{array}{c}\text { Diagnostic/ prescriptive teaching is better done by } \\
\text { resource room or special teachers than regular- } \\
\text { classroom teachers. }\end{array}$ & 2.93 & 0.78 & Agree \\
\hline $\begin{array}{c}\text { The inclusion of students with special needs can be } \\
\text { beneficial to regular students. }\end{array}$ & 2.73 & 0.79 & Agree \\
\hline $\begin{array}{c}\text { Students with special needs need to be told exactly } \\
\text { what to do and how to do it. }\end{array}$ & 1.72 & 0.82 & Strongly Disagree \\
\hline $\begin{array}{c}\text { Inclusion is likely to have a negative effect on } \\
\text { emotional development of the students with special } \\
\text { needs. }\end{array}$ & 2.57 & 0.90 & Agree \\
\hline $\begin{array}{c}\text { Increased freedom in the classroom creates too much } \\
\text { confusion. }\end{array}$ & 2.52 & 0.91 & Agree \\
\hline $\begin{array}{c}\text { The students with special needs will be socially } \\
\text { isolated by regular classroom students. }\end{array}$ & 2.40 & 0.85 & Disagree \\
\hline $\begin{array}{c}\text { The inclusion of students with special needs will } \\
\text { necessitate extensive retraining of regular teachers. }\end{array}$ & 1.99 & 0.78 & Disagree \\
\hline $\begin{array}{c}\text { Students with special needs should be given every } \\
\text { opportunity to function in the regular classroom } \\
\text { setting where possible. }\end{array}$ & 3.24 & 0.73 & Agree \\
\hline $\begin{array}{c}\text { Inclusion of students with special needs creates } \\
\text { confusion in regular classroom. }\end{array}$ & 2.46 & 0.80 & Disagree \\
\hline $\begin{array}{c}\text { The presence of students with special needs will } \\
\text { promote acceptance of differences on the part of } \\
\text { regular students. }\end{array}$ & 3.32 & 0.81 & Strongly Agree \\
\hline Grand Mean & 2.74 & 0.82 & Agree \\
\hline
\end{tabular}

Table 3: Attitude of Pre-Service Teachers toward Inclusive Education

WM=Weighted Mean SD=Standard Deviation

3.26-4.00 = Strongly Agree; 2.51-3.25 =Agree; 1.76-2.50 = Disagree; $1.00-1.75$ = Strongly Disagree

On the other hand, they strongly disagree that students with special needs need to be told exactly what to do and how to do it (WM=1.72). This means that the participants are convinced that students with special needs possess certain functionality.

Furthermore, the participants disagree that: the students with special needs will probably develop academic skills more rapidly in a special class than in a regular classroom (WM=2.22); most students with special needs do not make adequate attempt to complete their assignments (WM=2.41); they are well behaved in the classroom (WM=2.21); they will monopolize the teachers' time (WM=2.46); it is likely that a student with special needs will exhibit behavior problems in a regular classroom setting (WM=2.28); they will be socially isolated by regular classroom students $(\mathrm{WM}=2.40)$; the inclusion of students with special needs will necessitate extensive retraining of regular teachers (WM=1.99); and it creates confusion in regular classroom (WM=2.46). Given this attitude, it is evident that many of the participants do not have adequate understanding of the behavior of learners with special needs.

From the FGD results one participant shared her experience about having a classmate with special needs way back in Grade 6:

Not really sir. The same as what Vince has said about not putting them together in the same class. I had a classmate in grade 6 , and he never listened to our teacher. He crawled in class and our classmates laughed at him. He was bullied for acting childlike, and he would just cry. So, our teacher would just let him draw, and isolate him to the prayer room so he could calm himself. Despite this, he has really good grades because his mother often donated.---Ivy

This experience gave her the perspective that learners with special needs must not be included in the general education classroom. The other participants expressed their contention in saying no to inclusive education as follows:

No sir. It would be really difficult for you as a teacher. If you didn't have a background, you didn't know what the student's ailment is, you didn't know his characteristics how were you able to deal with him/ her? Unless you had real exposure or even just knowledge about it. ---Winnie

For me, it is really a "no'. It is not only good for teachers, we also lack facilities. Actually, when you talk about special education, each child has a special case. Hence, their classrooms must be very special for them too. If a child, for example, throws tantrums what are you going to do about it? Most regular classrooms' walls are made of cement. In special education classrooms, are like thrift hub. Their walls are made soft so it can prevent students from injuring themselves worse. They need special facilities that would compensate to their special needs. Therefore, it would be burdensome for the teacher and for other students who may have to adjust with these kind of learners. ---Tati

No, sir. Not all people can understand them. It would be very hard for them to cope. In my nephew's case, when we bring him to malls, he will definitely insist on buying something he really likes. So, we really have to buy it because he will go wild if we don't. There was also once that he got lost at a 
shopping mall. We toured the entire mall; we even had him called through intercom, but we still could not find him. We saw him where the toy he wanted to buy was. We were surprised that in his condition he was able to memorize how to get there. Not all people would really understand them when they throw tantrums. When they play with their hands, they think it's normal, but others would think otherwise, and they would get bullied about it. People would ridicule them.---Vince

I don't think so. Children with special needs really require special attention. That is why they have to have their own classroom which facilities fit to them. It is difficult too if you were the teacher. You must have the necessary experience in handling students like them. So, I don't wonder why the teacher of that school we visited totally ran out of patience. She had students running around, some were withdrawn, others were dancing, a few were reading, and the rest were just silent. If I were the teacher, I don't think they should be all in the same classroom.---Payos

For me, it is a no. Mainstreaming students with special needs would mean applying the same approaches and pedagogies with the regular students. As we have learned, students are different in terms of learning styles and ways of learning but they can cope with the same strategy or pedagogy. I don't think students with special needs can.---Ivy Tan

I also don't support sir. Why? Because special education is way too different from general education. Special education has modified curriculum which really fit for them. If they were mixed with regular students, they would have difficulties catching up the lessons. However, if they're in a special education, the teacher can really focus on how they can learn best. Unlike the United States, the Philippines is still not accepting. In fact they are often the center of bullying and discrimination, and you cannot avoid for it to happen. ---Criza

FGD participants Kei, Cindy, Bel, Pama, Jay and Jane are of the same perspective of not supporting inclusive education. For them, it takes qualified and competent teachers to handle learners with special needs and many teachers do not possess the necessary qualifications. Besides, they believe that somehow students with special needs may hinder the academic growth of non-special students in their class.

This finding is consistent with the results of the study of Angeles (2009). The teacher participants pointed out that it is difficult to handle children with special needs without prior experience on how to handle specific learning disabilities. Thus, they proposed to have an intensive and well-planned in-service training on instruction with appropriate curriculum to address the inclusive education shift. For Van Ruesen (2001), he found out that the most negative views about inclusive education are held by teachers with little or no training in special education.

On the other hand, two FGD participants are supportive of inclusive education saying:

For me sir. I think it is possible that students with special needs may be welcomed in a regular class because it is a challenge that we don't give to the students, but to the teacher. The prejudices about them get really serious and I think, it is unfair. Although they're special, they should be treated equally like us because they also have the same rights like ours. For me, it will definitely stop the bullying although it cannot be avoided. By exposing them to normal people, they could not be viewed as damaged, scarred or different. As teacher, we must treat all our students the same regardless of their race or skills. Although, it would also be difficult to have them in mainstream class, we must be open to possibilities of inclusion.---Padilla

Yes sir, so that children with special needs will have exposure, and people will begin to accept and treat them equally the same as typical children. ---Ray

Padilla who is supportive of inclusive education has exposure to a male cousin with disability. This is supported by studies in Australia particularly by Harvey (1985) who found out that individuals who have members in the family or a close friend with disability, may have more positive attitude towards policies on inclusive education.

The FGD results revealed that majority of the participants do not support inclusive education. However, when asked about what kind of training do they think is useful in preparing pre-service teachers like them to be better prepared to teach students with special needs in the mainstream classroom, six participants said seminars and symposia while the majority (9) said immersion/ exposure/ hands-on/ field study/ case study.

This finding is in consonance with the results of the preliminary cross-cultural study by Leyser, Kapperman and Keller (1994) on teachers' attitudes towards mainstreaming. The study revealed that majority of the Filipino teachers surveyed had a neutral disposition towards mainstreaming. The authors claimed that this disposition can be attributed to cultural, ethnic and religious differences, and concluded that existing educational problems, such as the unavailability of support services, may explain their perceptions.

Moreover, the study Al-Zyoudi (2006) conducted in Jordan found out that the nature and severity of the disability presented to the teachers and the length of teaching experience and training strongly influence the attitudes of teachers.

4.3. Problem 3 Is There a Significant Relationship between the Teachers' Past Experiences, Newly Acquired Knowledge, and Attitude toward Inclusive Education?

Table 4 presents the relationship between the teachers' past experiences, newly acquired knowledge, and attitude toward inclusive education. The data presented show that there is a significant relationship between the pre-service teachers' past experiences and newly acquired knowledge on inclusive education as evidenced by the obtained coefficient of correlation at 0.257 with significance level .000 indicating significance and rejection of the null hypothesis. This means that the participants' past experiences significantly influence their newly acquired knowledge on inclusive education. 
Moreover, there is no significant relationship between past experiences and attitude toward inclusive education and between newly acquired knowledge and attitude toward inclusive education as evidenced by the obtained coefficients of correlation at 0.037 (with significance level .000) and 0.092 (with significance level .130) respectively. Therefore, the study failed to reject the null hypotheses.

\begin{tabular}{|c|c|c|c|c|c|c|}
\hline \multicolumn{2}{|c|}{ Variable } & r & DR & $\begin{array}{c}\text { Sig. } \\
\text { Level }\end{array}$ & $\begin{array}{c}\text { Interpreta- } \\
\text { tion }\end{array}$ & Decision \\
\hline $\begin{array}{c}\text { Past } \\
\text { Experiences }\end{array}$ & $\begin{array}{c}\text { Newly } \\
\text { Acquired } \\
\text { Knowledge }\end{array}$ & $0.257^{* *}$ & $\begin{array}{c}\text { Negligible } \\
\text { correlation }\end{array}$ & .000 & Significant & Reject Ho \\
\hline $\begin{array}{c}\text { Past } \\
\text { Experiences }\end{array}$ & $\begin{array}{c}\text { Attitude } \\
\text { toward } \\
\text { inclusive } \\
\text { education }\end{array}$ & 0.037 & $\begin{array}{c}\text { Negligible } \\
\text { correlation }\end{array}$ & .541 & $\begin{array}{c}\text { Not } \\
\text { Significant }\end{array}$ & $\begin{array}{c}\text { Do not } \\
\text { Reject Ho }\end{array}$ \\
\hline $\begin{array}{c}\text { Newly } \\
\text { Acquired } \\
\text { Knowledge }\end{array}$ & $\begin{array}{c}\text { Attitude } \\
\text { toward } \\
\text { inclusive } \\
\text { education }\end{array}$ & 0.092 & $\begin{array}{c}\text { Negligible } \\
\text { correlation }\end{array}$ & .130 & $\begin{array}{c}\text { Not } \\
\text { Significant }\end{array}$ & $\begin{array}{c}\text { Do not } \\
\text { Reject Ho }\end{array}$ \\
\hline
\end{tabular}

Table 4: Relationship between Pre-Service Teachers' Past Experiences,

Newly Acquired Knowledge and Attitude toward Inclusive Education

Legend: $\mathrm{r}=$ correlation value; $\mathrm{DR}=$ descriptive rating; $\mathrm{Ho}=$ null hypothesis

\pm 0.00 to 0.30 (Negligible correlation);

\pm 0.31 to 0.50 (Low correlation);

\pm 0.51 to 0.70 (Moderate correlation);

\pm 0.71 to 0.90 (High correlation);

\pm 0.91 to 1.00 (Very high correlation);

**Significant at 0.01 alpha level

In the study of Parasuram (2006) exploring the variables that affect teachers' attitudes towards disability and inclusive education in Mumbai, India, it was found out that among the variables explored, prior acquaintance with a person with disability is the only variable that influence teachers' attitude. This appears to contradict with the findings of the study. However, as can be gleaned from the FGD results (see Appendix D), eight out of 15 participants have favourable attitude toward inclusive education. This is true for Winnie, Tati, Padilla, Ray, Kei, Cindy, Bel and Jay. Also, all but one had prior acquaintance with person with special needs.

In the words of Pama below, it is clear that attitude toward inclusive education is more than the function of past experience and newly acquired knowledge:

Honestly, I am not willing to teach children with special needs. However, if I were given the proper

training and having the right confidence with my skills, I would be willing to teach children with

special needs. For now, I don't think I am ready. ---Pama

Attitude in this case is definitely influenced by proper training that gives teachers confidence with their competence to handle learners with special needs. The study of Sharma, et. al. (2008) on the impact of training on preservice teachers' attitudes and concerns about inclusive education and sentiments about persons with disabilities supports this. The study obtained data from 603 pre-service teachers from Australia, Canada, Hongkong and Singapore. Likewise, this result finds support from De Boer, Pijl, and Minnaert (2011) who reviewed literature on regular primary schoolteachers' attitudes towards inclusive education. Twenty-six studies were analysed to find out the attitudes of teachers and the variables related to it. The results showed that teachers have neutral or negative attitudes towards inclusion of primary learners with special needs in regular classroom. Variables found to influence the teachers' attitude include training and experience with inclusive education and the learners' type of disability.

\section{Conclusion}

From the findings, this study concludes that only few of the pre-service teachers included in the study have exposure to inclusive education and this is in terms of trainings/ seminars and/or working with learners with special needs. This past experiences are found to significantly correlate with the participants' newly acquired knowledge. However, there is no significant relationship between past experiences and attitude toward inclusive education and newly acquired knowledge and attitude toward inclusive education. Thus, attitude toward inclusive education is more than the function of past experiences and newly acquired knowledge. It is adequate preparation that gives teachers confidence with their competence to handle learners with special needs.

\section{References}

i. $\quad$ Ainscow, M., \& Miles, S. (2008). Making Education for All inclusive: where next? Prospects, 38(1), 15-34.

ii. Aldridge, J., \& Fraser, B. (2000). A cross-cultural study of classroom learning environments in Australia and Taiwan. Learning Environments Research, 3(2), 101-134.

iii. Allday, R. A., Neilsen-Gatti, S., \& Hudson, T. M. (2013). Preparation for inclusion in teacher education pre-service curricula. Teacher education and special education, 36(4), 298-311. 
iv. Alur, M. (2002). Special needs policy in India. Education and children with special needs: from segregation to inclusion, 51-66.

v. Al-Zyoudi, M. (2006). Teachers' Attitudes towards Inclusive Education in Jordanian Schools. International Journal of Special Education, 21(2), 55-62.

vi. Ajzen, I., \& Fishbein, M. (1977). Attitude-behavior relations: A theoretical analysis and review of empirical research. Psychological bulletin, 84(5), 888.

vii. Beck, L., \& Ajzen, I. (1991). Predicting dishonest actions using the theory of planned behavior. Journal of research in personality, 25(3), 285-301.

viii. Campbell, J., Gilmore, L., \& Cuskelly, M. (2003). Changing student teachers' attitudes towards disability and inclusion. Journal of Intellectual and Developmental Disability, 28(4), 369-379.

ix. De Boer, A., Pijl, S. J., \& Minnaert, A. (2011). Regular primary schoolteachers' attitudes towards inclusive education: A review of the literature. International journal of inclusive education, 15(3), 331-353.

x. De Vaus, D. A., \& de Vaus, D. (2001). Research design in social research. Sage.

xi. Flem, A., \& Keller, C. (2000). Inclusion in Norway: A study of ideology in practice. European Journal of Special Needs Education, 15(2), 188-205.

xii. Gall, M. D., Borg, W. R., \& Gall, J. (1996). Educational Research, an Introduction. Sixth edition, Longman. Ney York.

xiii. Griffin, S., Ed, M., \& Shevlin, M. (2011). Responding to special educational needs: An Irish perspective. Gill \& Macmillan.

xiv. Klinger, J. K., Vaughn, S., Hughes, M. T., Schumm, J. S., \& Elbaum, B. (1998). Outcomes and without learning disabilities. Learning Disabilities Research and Practice, 13(3), 153-161.

xv. Larrivee, B., \& Cook, L. (1979). Mainstreaming: A study of the variables affecting teacher attitude. The journal of special education, 13(3), 315-324.

xvi. Leyser, Y., Kapperman, G., \& Keller, R. (1994). Teacher attitudes toward mainstreaming: a cross-cultural study in six nations. European Journal of Special Needs Education, 9(1), 1-15.

xvii. Loreman, T. (2007). Seven Pillars of Support for Inclusive Education: Moving from. International Journal of Whole Schooling, 3(2), 22-38.

xviii. Mastropieri, M. A., \& Scruggs, T. E. (2001). Promoting inclusion in secondary classrooms. Learning Disability Quarterly, 24(4), 265-274.

xix. Norwich, B. (1994). The relationship between attitudes to the integration of children with special educational needs and wider socio-political views; a US-English comparison. European Journal of Special Needs Education, 9(1), 91-106.

xx. Ostrom, T. M. (1969). The relationship between the affective, behavioral, and cognitive components of attitude. Journal of experimental social psychology, 5(1), 12-30.

xxi. Parasuram, K. (2006). Variables that affect teachers' attitudes towards disability and inclusiveeducationin Mumbai, India. Disability \& Society, 21(3), 231-242.

xxii. Pham, H. T. M. (2008). Attitudes Towards Inclusive Education of Students with Disabilities in Vietnam: A Survey of Regular Lower Secondary School Teachers (Master's thesis).

xxiii. Shade, R. A., \& Stewart, R. (2001). General education and special education preservice teachers 'attitudes toward inclusion. Preventing School Failure: Alternative Education for Children and Youth, 46(1), 37-41.

xxiv. Sharma, U., Forlin, C., \& Loreman, T. (2008). Impact of training on pre-service teachers' attitudes and concerns about inclusive education and sentiments about persons with disabilities. Disability \& Society, 23(7), 773-785.

xxv. Snyder, R. F. (1999). Inclusion: A qualitative study of in-service general education teachers' attitudes and concerns. Education, 120(1), 173-173.

xxvi. http:/ / www.deped.gov.ph/ 2009/ 07/ 06/ do-72-s-2009-inclusive-education-as-strategy-for-increasingparticipation-rate-of-children/

xxvii. https:// www.savethechildren.org.uk/ what-we-do/ childrens-rights/ united-nations-convention-of-the-rights-ofthe-child

xxviii. http:/ / www.unesco.org/ education/ sne/

xxix. https:/ / unesdoc.unesco.org/ ark:/ 48223/ pf0000177849

xxx. https:/ / unesdoc.unesco.org/ ark:/ 48223/ pf0000137333

xxxi. http:// bit.do/ eGKJC 